\title{
THE ANATOMY OF THE SUPERFICIAL EXTERNAL PUDENDAL ARTERY: A QUANTITATIVE STUDY
}

\author{
Osvaldir Lanzoni La Falce ${ }^{a}$, João Dias Ambrosio ${ }^{b}$, Romeu Rodrigues de Souza ${ }^{c}$
}

La Falce OL, Ambrosio JD, de Souza RR. The anatomy of the superficial external pudendal artery: a quantitative study. CLINICS. 2006;61(5):441-4.

The importance of the superficial external pudendal artery in cases of lower limb obstructive arteriopathies has been established, and a perfect knowledge of its anatomy is desirable for the creation of successful flaps involving it. However, little information is available on the morphometry of this artery.

PURPOSE: In this study, we conducted a quantitative investigation of the superficial external pudendal artery as the basis for skin grafts.

METHOD: Twenty-five right and left sides of the inguinal region of male cadavers were dissected. After retracting the skin at the inguinal region, the femoral vessels and the sapheno-femoral junction were exposed. The following aspects were then analyzed: 1) the presence of the superficial external pudendal artery, 2) the place of origin of the superficial external pudendal artery and the common trunk, 3) the duplication of the superficial external pudendal artery, 4) the distance from the superficial external pudendal artery or the common trunk to the inguinal ligament, and 5) the diameter of the superficial external pudendal artery.

RESULTS: The results were the following: 1) superficial external pudendal arteries were found in 46 of 50 sides (92\%); 2) they originated from the femoral artery in 45 cases and from the deep femoral artery in only 1 case; 3 ) the arteries were found duplicated in 21 cases $(46 \%)$, as a common trunk in 11 cases $(24 \%)$, and as a single artery in 14 cases $(30 \%)$; 4) the distance from the superficial external pudendal artery to the inguinal ligament ranged from $0.8 \mathrm{~cm}$ to $8.5 \mathrm{~cm}$; from the common trunk, it ranged from $3.5 \mathrm{~cm}$ to $6.7 \mathrm{~cm} ; 5)$ the diameter of the superficial external pudendal artery ranged from $1.2 \mathrm{~mm}$ to $3.8 \mathrm{~mm}$; and 6 ) the diameter of the common trunk ranged from $1.35 \mathrm{~mm}$ to $5.15 \mathrm{~mm}$.

CONCLUSION: The results show that the superficial external pudendal artery generally originates from the femoral artery. It was found as a common trunk, duplicated, or as a single artery. There was a great variability in both the diameter of the artery and the distance from the artery to the inguinal ligament. Most of the data showed no significant differences between the right and the left sides.

KEYWORDS: Superficial external pudendal artery. Anatomy. Morphometry

\section{INTRODUCTION}

The importance of the superficial external pudendal artery (SEPA) in cases of lower limb obstructive

aDepartment of Anatomy, São Camilo University Center - São Paulo/SP, Brasil.

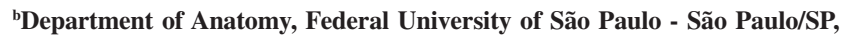
Brasil.

'Department of Anatomy, São Judas Tadeu University, Institute of Biomedical Sciences, São Paulo University - São Paulo/SP, Brasil

Email: souzarrd@uol.com.br

Received for publication on May 23, 2006.

Accepted for publication on June 20, 2006. arteriopathies has been established by several authors. ${ }^{1,2}$ Furthermore, SEPA flaps have been used in the repair of skin defects of the penile shaft after placement of a prosthesis, ${ }^{3}$ in the vulvar reconstruction, ${ }^{4}$ and in the reconstruction of hand skin injuries. ${ }^{5,6}$ The SEPA radiates out from the saphenous opening and gives rise to branches that are arranged in a roughly radial fashion. ${ }^{7}$

The artery was found to be adequate in caliber and length to sustain a skin flap on either side of the midline, extending from the symphysis pubis to the umbilicus. ${ }^{7}$ The arterial system of the SEPA almost certainly provides the blood supply for the flap used in the phalloplasty to re- 
construct the male genitalia. ${ }^{8}$ Although an accurate knowledge of the anatomy of the vessel is of maximal importance for designing an axial pattern flap, there is only 1 study in the literature describing the anatomy of this artery ${ }^{7}$ and none describing its mode of origin. In that study, 12 dissections were performed on cadavers, and the anatomy of the vessels was descibed, as was their distal extent, and their cross-connections ${ }^{7}$ The report states that the SEPA always arises from the medial side of the femoral artery at the level of the sapheno-femoral junction, and that the vessel is $2 \mathrm{~mm}$ in diameter at its origin. Thus, more information on the morphometry of the artery is needed.

The purpose of this work was to accurately describe the quantitative aspects of the superficial external pudendal artery in men.

\section{METHOD}

In this study, 25 male adult cadavers with ages varying from 28 to 60 years were used, 16 white and 9 nonwhite, preserved in $10 \%$ formaldehyde solution.

Initially, an incision was made right below and parallel to the inguinal ligament to expose the femoral vessels and the sapheno-femoral junction. Then, the skin, the subcutaneous tissue, and the fascia lata of the anterior region of the thigh was retracted. The origin of the SEPA was thus exposed. The SEPA was then dissected medially in the direction of the scrotum to the pubic symphysis and to the penis. Both the right and left sides of the arteries were evaluated, adding up to a total of 50 sides.

The following aspects were observed: 1) the presence of the artery; 2) the duplication of the artery; 3) the distance between the origins of the two arteries, when duplicated; 4) the place of origin of the SEPA and its common trunk; 5) the distance from the SEPA from the common trunk to the inguinal ligament; 6) with the aid of a caliper, we measured the diameter of the artery at its origin; 7) the common trunk length and diameter.

The data obtained for the frequency of the SEPA were compared using the chi-square test; the other results were compared using the Student $t$ test.

\section{RESULTS}

The artery was found in 46 of the 50 sides (92\%); It originated at the deep femoral artery in 1 case $(2 \%)$ and from the femoral artery in 45 cases (98\%) (Table 1). In all cases, the SEPA originated at the medial side of the femoral artery, pierced the fascia of the thigh, and passed superomedially towards the pubic symphisis. From this point, it then continued upwards towards the umbilicus. At this point, it divided into 3 or 4 terminal branches (Figure 1).

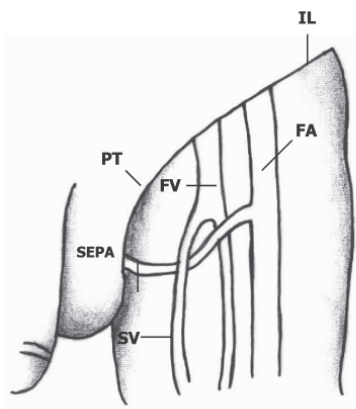

A

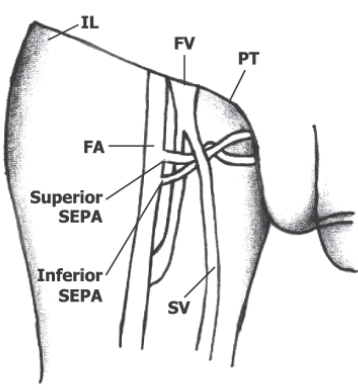

C

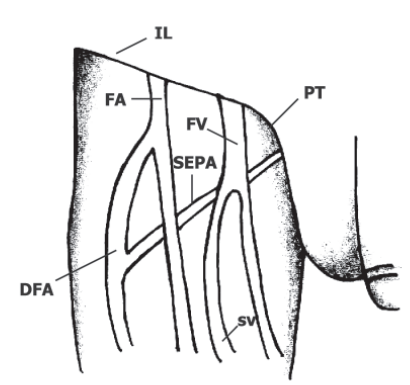

B

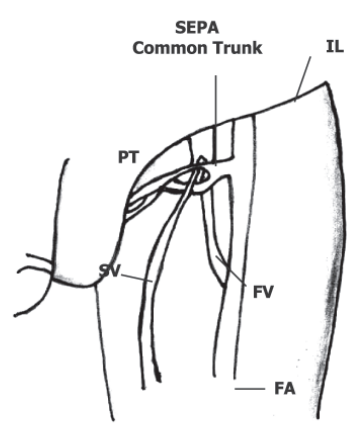

D
Figure 1 - Types of distribution of the superficial external pudendal artery (SEPA). A) single artery; B) artery originating at the deep femoral artery; C) artery with double origin; D) artery with a common trunk; FA, femoral artery; FV, femoral vein; SV, saphenous vein; PT, pubic tubercle; IL, inguinal ligament; DFA, deep femoral artery.

The SEPA was found to be duplicated in 21 cases (46\%); the division produced a superior superficial external pudendal artery and an inferior superficial external pudendal artery on 10 occasions on the right side and on 11 occasions on the left side. It was found as a common trunk in 11 cases (24\%), 4 cases on the right side and 7 cases on the left side. In 14 cases it was found as a single artery, (30\%), 9 cases for the right side and 5 cases for the left side (Figure 1 and Table 1). No significant difference was observed when the data for the right and left sides were compared.

When the artery was found to be duplicated, the distances between the origins on the same side varied from nearly $0 \mathrm{~cm}$ to $4.3 \mathrm{~cm},(0.68 \pm 0.5 \mathrm{~cm}$ for the right side and $1.56 \pm 1.2$ for the left side - mean \pm SD). The means for the right and left sides were not significantly different (Table 1).

The distance from the SEPA or from the common trunk to the inguinal ligament varied from $0.8 \mathrm{~cm}$ to $8.5 \mathrm{~cm}(5.3$ \pm 0.87 for the right side and $4.8 \pm 1.0 \mathrm{~cm}$ for the left side - mean $\pm \mathrm{SD}$ ). The means for the right and left sides were not significantly different. 
Table 1 - Quantitative data of the superficial external pudendal artery (SEPA) by side of occurrence (46 dissections)

\begin{tabular}{lcc}
\hline Frequency (number) and \% of the SEPA & Right Side & Left Side \\
\hline Single & $9(39 \%)$ & $5(22 \%)$ \\
Duplicated & $10(43 \%)$ & $11(48 \%)$ \\
Common trunk & $4(17 \%)$ & $7(30 \%)$ \\
Mean \pm SD of the distances (cm) between the origins of the SEPA to the inguinal ligament & $5.3 \pm 0.87$ & $4.8 \pm 1.0$ \\
Mean of the distances (cm) \pm SD between the superior SEPA and inferior SEPA & $0.68 \pm 0.5$ \\
Mean \pm SD of the diameters (mm) of the SEPA & $2.52 * \pm 0.91$ \\
Single & $2.21 \pm 0.22$ & $1.56 \pm 1.2$ \\
Superior SEPA & $2.18 * \pm 0.63$ & $1.66 \pm 0.51$ \\
Inferior SEPA & $3.11 \pm 1.50$ & $1.95 \pm 0.64$ \\
Common Trunk & $0.9 \pm 0.2$ & $3.55 \pm 0.96$ \\
Length of the common trunk (cm) & $1.0 \pm 0.5$ \\
\hline
\end{tabular}

* Significantly different from the left side $(P<0.05)$

The SEPA diameter varied from $1.2 \mathrm{~mm}$ to $3.8 \mathrm{~mm}$. Comparison between right and left sides showed significant differences in the mean diameters for single SEPA and for the inferior SEPA $(P<0.05)$ (see Table 1). The common trunk length varied from $0.6 \mathrm{~cm}$ to $1.9 \mathrm{~cm}(0.9 \pm 0.2$ $\mathrm{cm}$ for the right side and $1.0 \pm 0.5 \mathrm{~cm}$ for the left side mean $\pm \mathrm{SD}$ ). The means for the right and left sides were not significantly different.

\section{DISCUSSION}

In order to create a successful flap, it is important to understand the anatomy of the arteries that promote its vascularization, ${ }^{7,9}$ a fact which obviously applies to the flaps involving the superficial external pudendal artery. However, only 1 study has been published on the distribution of the superficial external pudendal artery, ${ }^{7}$ in which the authors thoroughly describe the itinerary of the superficial artery extension and connections. However, they made no reference to measurements or where or how the artery originates, as we have done in the present study. Additionally, their data was based on only 12 dissections; therefore, it was not possible to reach any significant conclusion regarding the anatomical arterial variations.

We found the artery in 46 of the 50 dissected sides, on 32 occasions as duplicated arteries and as single arteries on 14 occasions. In just 1 case, the artery did not originate from the femoral artery but rather from the deep femoral artery. We observed great variation in the distance between the artery and the inguinal ligament, ie, $0.8 \mathrm{~cm}$ to $8.5 \mathrm{~cm}$. When the artery was found to be duplicated, the distance between the arteries varied from nearly 0 to 4.3 $\mathrm{cm}$. The diameter of the artery varied from 1.35 to 5.15 $\mathrm{mm}$. According to other authors ${ }^{10}$ the diameter of the artery at its origin is $2 \mathrm{~mm}$. Most of the parameters measured showed no significant differences between the right and left sides.

The results of this study increases our knowledge of the anatomy of the superficial external pudendal artery. This knowledge is considered to be an essential and invaluable preliminary step in clinical research of this nature. ${ }^{7}$

\section{RESUMO}

La Falce OL, Ambrosio JD, de Souza RR. Anatomia da artéria pudenda superficial externa: estudo quantitativo. CLINICS. 2006;61(5):441-4.

A importância do conhecimento da anatomia da artéria pudenda superficial externa está bem estabelecida e um conhecimento adequado de sua anatomia é desejável para a criação bem sucedida de flaps. Entretanto, são escassos os trabalhos morfométricos sobre esta artéria.

OBJETIVO. No presente estudo, foi feita uma análise quantitativa da artéria pudenda superficial externa, como base para enxertos de pele.
MÉTODO. Foram dissecadas 25 regiões inguinais direitas e 25 esquerdas de cadáveres do sexo masculino. Após rebater a pele da região inguinal, os vasos femorais, a junção safeno-femoral e a artéria pudenda superficial externa foram expostas. Os seguintes aspectos foram então analisados: 1. Presença da artéria pudenda superficial externa; 2. Local de origem da artéria pudenda superficial externa ou do tronco comum; 3. Duplicação da artéria pudenda superficial externa; 4. Distância da artéria pudenda superficial externa ou do tronco comum ao ligamento inguinal; 5. Diâmetro da artéria pudenda superficial externa.

RESULTADOS. Os resultados mostraram que: 1. A arté- 
ria pudenda superficial externa foi encontrada em 46 dos 50 lados dissecados $(92 \%)$; 2 . A artéria teve origem na artéria femoral em 45 casos; em um único caso teve origem na artéria femoral profunda; 3. A artéria foi encontrada duplicada, em 21 casos (46\%), formando um tronco comum, que depois se bifurcava, em 11 casos (24\%) e como uma artéria única 14 vezes (30\%); 4. A distância da artéria ao ligamento inguinal variou de $0,8 \mathrm{~cm}$ a $8,5 \mathrm{~cm}$; quando sob a forma de tronco comum, esta distância variou de $3,5 \mathrm{~cm}$ a $6,7 \mathrm{~cm} ; 5$. O diâmetro da artéria pudenda superficial externa variou de $1,36 \mathrm{~mm}$ a $5,15 \mathrm{~mm}$.
CONCLUSÕES. Os resultados mostram que a artéria pudenda superficial externa origina-se, na grande maioria dos casos, da artéria femoral. Foi encontrada como um tronco comum, duplicada ou como uma artéria única. O diâmetro da artéria mostrou grande variabilidade assim como a distância da artéria ao ligamento inguinal. A maioria dos dados não mostrou diferença significante entre os lados direito e esquerdo.

UNITERMOS: Artéria pudenda superficial externa. Anatomia Morfometria.

\section{REFERENCES}

1. Renard M, Brice M, Borelli J, Stehin P, Schimitt M, Masson JP. Les voies de supléance des axes artériels ilio - femouraux (étude radio anatomique). C R Ass Anat, Liège. 1974,58:649-60.

2. Macchi C, Giannelli F, Cecchi F, Corcos L, Repice F, Cantini C, et al. Collateral circulation in occlusion of lower limbs arteries: an anatomical study and statistical research in 35 old subjects. It J Anat Embryol. 1996;101:89-96.

3. Abe ST, Yamaguchi Y, Hata K, Yamaguchi T. Penile reconstruction with de-epithelized superficial external pudendal artery flap. J Urol. 1992;147:155-7.

4. Mayer AR, Rodriguez RL. Vulvar reconstruction using a pedicle flap based on the superficial external pudendal artery. Obstet Gynecol. 1991;78:964-8.

5. Thate RL, Patil UA, Dhami LD. The combined use of the superficial external pudendal artery flap with a flap of the anterior rectus sheath for the simultaneous cover of dorsal and volar defects on the hand, $\mathrm{Br} \mathrm{J}$ Plast Surg. 1986;39:321-6.
6. George A, Cunha Gomes D, Thatte RL. Early division of pedicled flaps using a simple devise: a new technique. Br J Plastic Surg. 1996;44:11922.

7. Patil UA, Dias AD, Thatte RL. The anatomical basis of the SEPA flap. Br J Plastic Surg. 1987;40:342-7.

8. Noe J, Birdsell D, Laud D. The surgical construction of male genitalia for the female to male transsexual. Plastic Reconst Surg. 1974;53:5118 .

9. Cormack G C, Lamberty B G H. The anatomical vascular basis of the axillary fascio-cutaneous pedicled flap. Br J Plastic Surg. 1983;36:42533.

10. Dias AD, Thatte RL, Patil VA, Dhami LD, Prasad S. The superficial external pudendal artery (SEPA) axial-pattern flap. Br J Plastic Surg. $1984 ; 37: 256-61$. 